\title{
EXPLORING POSSIBILITIES OF TRANSFORMATIVE LEARNING IN CONTINUING MEDICAL EDUCATION: A LITERATURE REVIEW
}

\author{
Reinis Upenieks \\ University of Latvia, Latvia
}

\begin{abstract}
Changes are inevitable part of all walks of life; adults from different professions more often than ever face new challenges when previous knowledge, skills and attitudes are ineffective. Transformative learning approaches could be of a great value in order to foster changes within a person - necessity in contemporary world. It is also true for medicine and medical professionals. However, longstanding traditions of medical education have established fundamentals, like, reliance on individual's professional performance rather than teamwork; sanctity of hardly acquired knowledge and fixed techniques rather than learning from error and continuous improvement.

As an adult educator himself, the author of this paper is interested in transformative learning possibilities within field of continuing medical education. By conducting a literature review the author seeks to answer the following question: what is the scope and the nature of research and studies devoted to transformative learning in continuing medical education? As a result of three tiers of search queries, 16 articles have been included in the literature review.

Main ideas of the studies reviewed are discussed in this paper. Several strains can be recognized: Operational level of introducing transformative learning in continuing medical education; Conceptual (theoretical) frameworks of possible introduction of transformative learning within continuing medical education; Transformative learning within undergraduate or graduate study context; Importance of self-monitoring and self-reflection of medical professionals; Importance of continuing medical education to adopt new teaching and learning approaches.
\end{abstract}

Keywords. Transformative learning; Continuing medical education; Literature review.

\section{Introduction}

Adults from different professions more often than ever face new challenges when previous knowledge, skills and attitudes are ineffective.

Transformative learning, according to the author of the transformative learning theory, Jack Mezirow, is "learning that transforms problematic frames of reference - sets of fixed assumptions and expectations (habits 
of mind, meaning perspectives, mindsets) - to make them more inclusive, discriminating, open, reflective, and emotionally able to change" (Mezirow, 2003, 58). Such an approach could be of a great value in contemporary, changing world.

There are hopeful expectations that education systems now from pre-school to university levels incorporate at least basic principles of transformative learning in order to prepare students for their upcoming life, also known as VUCA world. It is also true for medicine and medical professionals. However, for those already grounded in their profession for years there is additional challenge: longstanding traditions of medical education have established fundamentals, like, reliance on individual's professional performance rather than teamwork; sanctity of hardly acquired knowledge and fixed techniques rather than learning from error and continuous improvement.

Continuing professional development, namely, continuing medical education is the branch where, according to the believe of the author of this paper, it is important to introduce and to strengthen ideas of transformative learning, thus improving performance of medical professionals and ultimately, outcomes for patients.

What is done so far? In order to learn recent developments of transformative learning in the field of continuing medical education, author of this paper decided to conduct respective literature review.

\section{Searching tool, strategies, and results}

Searching tool deployed for the research was Primo Discovery service provided by ExLibris Group (a ProQuest Company) for University of Latvia. It is an effective tool for discovery and delivery information resources as it runs simultaneous search within all databases (Table 1) accessible for author's Alma Mater.

Table 1. List of databases accessible for University of Latvia (as on June 1, 2019)

\begin{tabular}{|l|}
\hline Name of database \\
\hline Dawsonera \\
\hline EBSCO \\
\hline EBSCO Central \& Eastern European Academic Source \\
\hline Emerald \\
\hline JSTOR \\
\hline LETA \\
\hline LETA - Arhivs \\
\hline
\end{tabular}




\begin{tabular}{|l|}
\hline Name of database \\
\hline Letonika \\
\hline Nozare.lv \\
\hline OECD iLibrary \\
\hline Oxford Journals \\
\hline ProQuest Dissertations \& Theses Global \\
\hline ProQuest Ebook Central \\
\hline Researcher ID (Thomson Reuters) \\
\hline SAGE Journals Online \\
\hline SAGE Research Methods \\
\hline ScienceDirect \\
\hline Scopus \\
\hline SpringerLink \\
\hline Taylor \& Francis Social Science \& Humanities Library \\
\hline Times Higher Education \\
\hline Web of Science \\
\hline
\end{tabular}

Two main key phrases for this research are: "transformative learning" and "continuing medical education", so they were used in the search query, looking for both phrases in subject field.

Search query 1 (Figure 1) revealed 6 results. All of them are articles in English from peer-review journals, published from 2007 to 2009. Although all six indicated having full text online, none of full texts were accessible for the author.

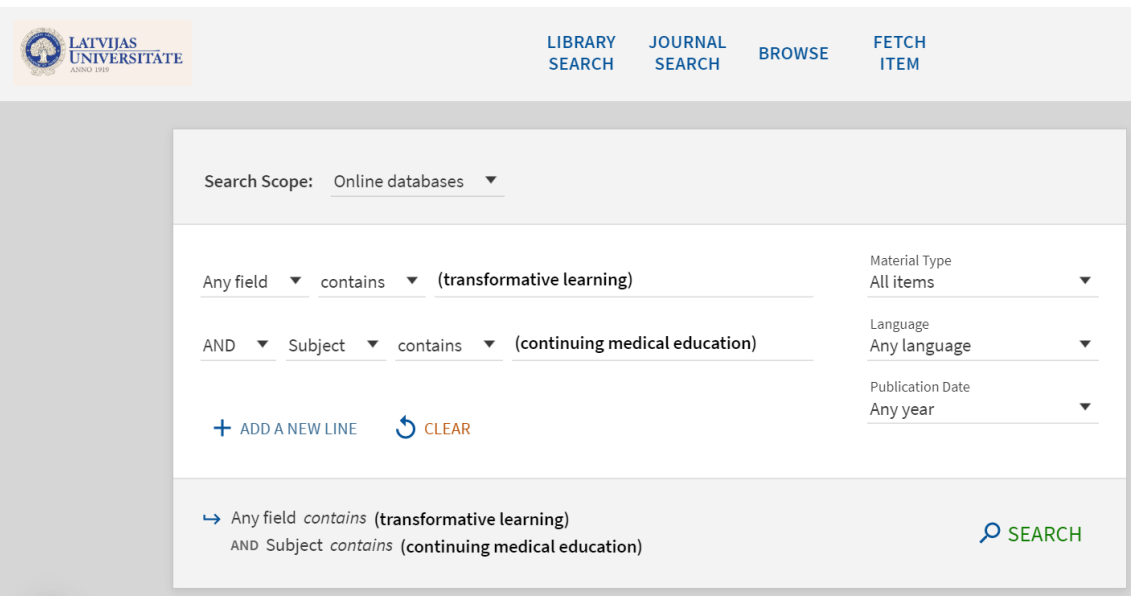

Figure 1. Screenshot of Primo search entry page (search query 1) 
Such an exclusive list of articles (Galbraith, et al. 2008; Ranson, et al., 2007; Mcwilliam, 2007; Dornan, 2008; Epstein, et al., 2008; Sargeant, 2009) seemed an underestimate of the topic, also given the fact that all six sources come from the same journal. So, author of this paper decided to expand search query, allowing phrase "continuing medical education" to be searched within any field.

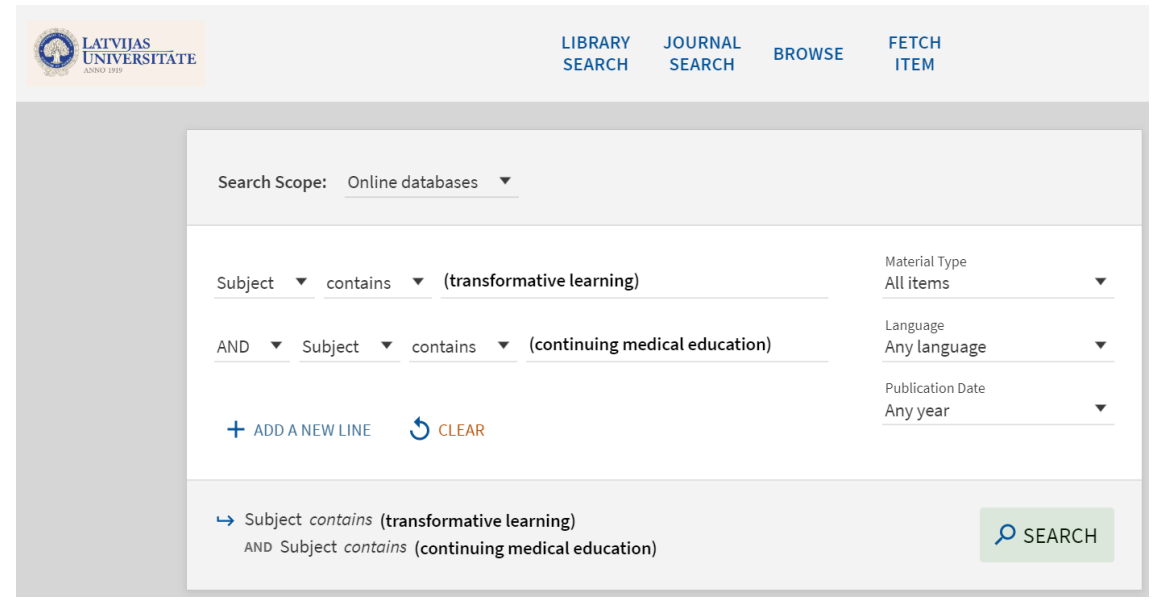

Figure 2. Screenshot of Primo search entry page (search query 2)

Search query two (Figure 2) revealed 40 results. All of them are articles in English from peer-review journals, published from 2007 to 2019. Thirtythree full-text sources out of 40 were accessible for the author of this paper. Six of non-accessible items were duplicates of search query one.

As next, analysis of keywords and summaries of those articles was performed. Looking for articles containing medic* or nurs* in their keywords or summaries revealed 14 articles (including previously found 6 articles in search query one).

List of these results are displayed in Table 2, citing articles along with their subjects / keywords and number of other articles citing them. 
Table 2. Narrowed list of articles revealed by search query Two (filtered for medic* or nurs* in their keywords or summaries)

\begin{tabular}{|c|c|c|c|}
\hline Article & \multicolumn{2}{|c|}{ Subjects / Keywords } & \multirow{2}{*}{$\begin{array}{c}\begin{array}{c}\text { Number } \\
\text { of articles } \\
\text { citing this }^{\text {source }}\end{array} \\
\text { sound }^{1} \\
51\end{array}$} \\
\hline $\begin{array}{l}\text { Epstein, R., } \\
\text { Siegel, D., \& } \\
\text { Silberman, J. } \\
\text { (2008). }\end{array}$ & $\begin{array}{l}\text { Physicians } \\
\text { Cognitive Psychology } \\
\text { Cognitive Style } \\
\text { Metacognition } \\
\text { Medical Education } \\
\text { Self Evaluation } \\
\text { (Individuals) } \\
\text { Clinical Experience } \\
\text { Transformative Learning }\end{array}$ & $\begin{array}{l}\text { Neuropsychology } \\
\text { Science Process Skills } \\
\text { Professional Continuing } \\
\text { Education } \\
\text { Self Management } \\
\text { Medicine } \\
\text { Education }\end{array}$ & \\
\hline $\begin{array}{l}\text { Sargeant, J. } \\
\text { (2009). }\end{array}$ & $\begin{array}{l}\text { Professional Continuing } \\
\text { Education } \\
\text { Interprofessional } \\
\text { Relationship } \\
\text { Interdisciplinary } \\
\text { Approach } \\
\text { Social Theories } \\
\text { Learning Theories } \\
\text { Medical Education }\end{array}$ & $\begin{array}{l}\text { Health Personnel } \\
\text { Transformative Learning } \\
\text { Social Psychology } \\
\text { Systems Approach } \\
\text { Communities of Practice } \\
\text { Reflection } \\
\text { Medicine } \\
\text { Education }\end{array}$ & 36 \\
\hline $\begin{array}{l}\text { Mcwilliam, C. } \\
\text { (2007). }\end{array}$ & $\begin{array}{l}\text { Educational Change } \\
\text { Transformative Learning } \\
\text { Health Personnel } \\
\text { Active Learning } \\
\text { Professional Continuing } \\
\text { Education } \\
\text { Medical Research } \\
\text { Research Utilization }\end{array}$ & $\begin{array}{l}\text { Health Services } \\
\text { Organizational Culture } \\
\text { Theory Practice } \\
\text { Relationship } \\
\text { Postsecondary Education } \\
\text { Educational Innovation } \\
\text { Medicine } \\
\text { Education }\end{array}$ & 21 \\
\hline $\begin{array}{l}\text { Galbraith, R., } \\
\text { Hawkins, R., \& } \\
\text { Holmboe, E. } \\
(2008) .\end{array}$ & $\begin{array}{l}\text { Medical Education } \\
\text { Lifelong Learning } \\
\text { Program Improvement } \\
\text { Professional Continuing } \\
\text { Education } \\
\text { Relevance (Education) } \\
\text { Change Strategies }\end{array}$ & $\begin{array}{l}\text { Program Effectiveness } \\
\text { Metacognition } \\
\text { Cognitive Style } \\
\text { Transformative Learning } \\
\text { Self Evaluation } \\
\text { (Individuals) } \\
\text { Medicine } \\
\text { Education } \\
\end{array}$ & 13 \\
\hline $\begin{array}{l}\text { Ranson, S., } \\
\text { Boothby, J., } \\
\text { Mazmanian, P., \& } \\
\text { Alvanzo, A. } \\
\text { (2007). }\end{array}$ & $\begin{array}{l}\text { Medical Education } \\
\text { Physicians } \\
\text { Access to Information } \\
\text { Program Effectiveness } \\
\text { Use Studies } \\
\text { Decision Support Systems } \\
\text { Information Technology } \\
\text { Portfolio Assessment }\end{array}$ & $\begin{array}{l}\text { Interviews } \\
\text { Questionnaires } \\
\text { Transformative Learning } \\
\text { Professional Continuing } \\
\text { Education } \\
\text { Medicine } \\
\text { Education }\end{array}$ & 12 \\
\hline
\end{tabular}

${ }^{1}$ Number of other articles citing source are subject to change. Number reflected in the table has been fixed at the time of preparing this paper. 


\begin{tabular}{|c|c|c|c|}
\hline Article & \multicolumn{2}{|c|}{ Subjects / Keywords } & \multirow{2}{*}{\begin{tabular}{|c|}
$\begin{array}{c}\text { Number } \\
\text { of articles } \\
\text { citing this } \\
\text { source }^{1}\end{array}$ \\
9
\end{tabular}} \\
\hline $\begin{array}{l}\text { Adamshick, \& } \\
\text { August-Brady. } \\
\text { (2012). }\end{array}$ & $\begin{array}{l}\text { RN-BS Students } \\
\text { Cultural Immersion }\end{array}$ & $\begin{array}{l}\text { Phenomenology } \\
\text { Transformative Learning }\end{array}$ & \\
\hline $\begin{array}{l}\text { Mcallister, M. } \\
\text { (2011). }\end{array}$ & $\begin{array}{l}\text { Critical Reflection } \\
\text { Transformative Education }\end{array}$ & $\begin{array}{l}\text { Transformative Learning } \\
\text { Education }\end{array}$ & 7 \\
\hline $\begin{array}{l}\text { Brendel, W. } \\
\text { (2009). }\end{array}$ & $\begin{array}{l}\text { Transformative Learning } \\
\text { Narrative Medicine } \\
\text { Clinical Dialogue }\end{array}$ & $\begin{array}{l}\text { End-of-Life Care } \\
\text { Education }\end{array}$ & 6 \\
\hline $\begin{array}{l}\text { Macdonnell, J., \& } \\
\text { Macdonald, G. } \\
\text { (2011). }\end{array}$ & $\begin{array}{l}\text { Transformative Learning } \\
\text { Arts-Based Education }\end{array}$ & $\begin{array}{l}\text { Critical Reflection } \\
\text { Education }\end{array}$ & 6 \\
\hline $\begin{array}{l}\text { Dornan, T. } \\
\text { (2008). }\end{array}$ & $\begin{array}{l}\text { Medical Education } \\
\text { Medical Students } \\
\text { Self Evaluation } \\
\text { (Individuals) } \\
\text { Foreign Countries } \\
\text { Professional Continuing } \\
\text { Education } \\
\text { Certification } \\
\text { Technology Integration } \\
\end{array}$ & $\begin{array}{l}\text { Intellectual History } \\
\text { Educational Development } \\
\text { Transformative Learning } \\
\text { Self Management } \\
\text { United Kingdom } \\
\text { Medicine } \\
\text { Education }\end{array}$ & 5 \\
\hline Moon, P. (2008). & \begin{tabular}{|l} 
Death \\
Grief \\
Terminal Condition \\
\end{tabular} & $\begin{array}{l}\text { Transformative Learning } \\
\text { Medicine }\end{array}$ & 4 \\
\hline $\begin{array}{l}\text { Mcallister, M. } \\
\text { (2015). }\end{array}$ & $\begin{array}{l}\text { Change } \\
\text { Critical Theory } \\
\text { Curriculum } \\
\end{array}$ & $\begin{array}{l}\text { Nursing Education } \\
\text { Transformative Learning }\end{array}$ & 3 \\
\hline $\begin{array}{l}\text { Sokol, R. G., \& } \\
\text { Shaughnessy, A. } \\
\text { F. (2018). }\end{array}$ & $\begin{array}{l}\text { Continuing } \\
\text { Education } \\
\text { Educational } \\
\text { Evidence-Based Medicine }\end{array}$ & $\begin{array}{l}\text { Learning } \\
\text { Models } \\
\text { Qualitative Research } \\
\text { Transformative Learning }\end{array}$ & 1 \\
\hline $\begin{array}{l}\text { Mcallister, Levett- } \\
\text { Jones, Petrini, \& } \\
\text { Lasater. (2016). }\end{array}$ & $\begin{array}{l}\text { Transformative Learning } \\
\text { Ethical Comportment } \\
\text { Film }\end{array}$ & $\begin{array}{l}\text { Teaching Strategy } \\
\text { Nursing Students }\end{array}$ & 1 \\
\hline
\end{tabular}

There was also the third search query performed in order to make certain not to miss any other applicable article: keeping phrase "continuing medical education" in subject field and looking for phrase "transformative learning" in any field. 


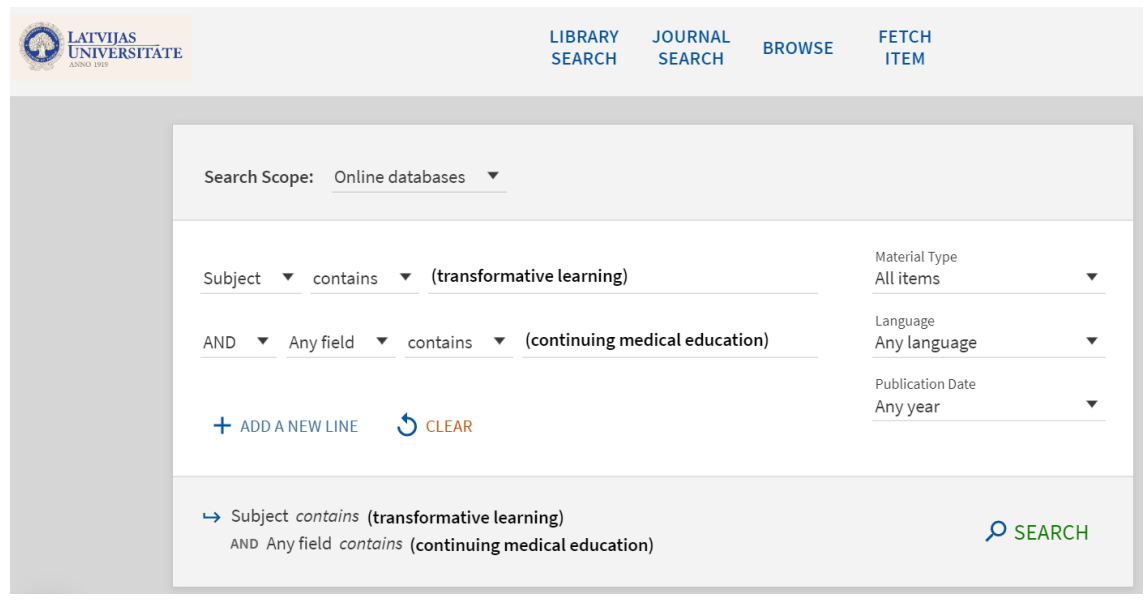

Figure 3. Screenshot of Primo search entry page (search query 3)

Such search query revealed 33 items. Refining by English language and Peer-reviewed categories made list of 27 items. Again, six of them were the same duplicates as in search queries one and two. The remaining 21 items were filtered by looking for transformative learning within their abstracts / notes. It resulted in finding 2 articles (Table 3).

Table 3. Additional matching articles after search query three

\begin{tabular}{|l|l|l|c|}
\hline \multicolumn{1}{|c|}{ Article } & \multicolumn{2}{|c|}{ Subjects / Keywords } & $\begin{array}{c}\text { Number } \\
\text { of articles } \\
\text { citing this } \\
\text { source }\end{array}$ \\
\hline $\begin{array}{l}\text { Skipper, M., } \\
\text { Musaeus, P., \& } \\
\text { Nahr, S. (2016). }\end{array}$ & $\begin{array}{l}\text { Continuing Medical } \\
\text { Education - Research } \\
\text { Patient Care - Research }\end{array}$ & $\begin{array}{l}\text { Ambulatory } \\
\text { Care Facilities - } \\
\text { Research }\end{array}$ & 16 \\
\hline Holmboe, E. (2008). & $\begin{array}{l}\text { Education } \\
\text { Medical } \\
\text { Continuing }\end{array}$ & $\begin{array}{l}\text { Assessment } \\
\text { Physicians-In- } \\
\text { Practice } \\
\text { Quality Of Care }\end{array}$ & 5 \\
\hline
\end{tabular}

As a result of three search queries applied, there are 16 articles found and included in further review. Nine full texts were accessible for the author at the time of preparation of this article; for other seven - abstract level information was analysed.

${ }^{2}$ Number of other articles citing source are subject to change. Number reflected in the table has been fixed at the time of preparing this paper. 


\section{Discussion}

For transformative learning to happen, there is absolute necessity of self-conscious meta-cognitive processes to take part. This is acknowledged challenge for medical educators, for instance, in most cited article (of those included in this literature review) about physicians' self-monitoring in clinical practice (Epstein, et al., 2008). It is stressed that self-monitoring is an important component of the professional competence of physicians. Also - thinking of "facts" as conditional, experiencing information as novel, seeing situations from multiple perspectives, suspending categorization and judgment, and engaging in self-questioning - are contrasted to being on" automatic pilot" or "mindless" in physicians' behaviour (Epstein, et al., 2008). Theoretical point is clear; however, how it could be fostered operationally in continuing medical education, is not discovered.

Another example of concise, still, theoretical conclusion is the one requiring continuing medical education to adopt new content, recognize new knowledge, and use new approaches for learning in order to strengthen interprofessional education (Sargeant, 2009). What one could find missing, is place and experience of actual participants of continuing medical education events designed for interprofessional collaboration.

Answer to that, at least, partly, can be found in another article promoting transformative knowledge translation (Mcwilliam, 2007). The article presents theory-based strategy for continuing medical education where clinicians are engaged in an on-the-job process of developing a deeply felt interest in research findings relevant to everyday practice, as well as ownership of that knowledge and its application (Mcwilliam, 2007). The role of continuing educator is described quite clear, and even missionary - to foster a learning organization culture across the institution; the role of learner is a bit inscrutable.

Right to the point of learner's perspective are Galbraith, et al., (2008). They acknowledge that although self-assessment is an important mechanism for lifelong learning and self-improvement for health care professionals, however, there is growing concern that individual learners often interpret the results inaccurately. In the course of the article they prove that selfassessment can and should be made more effective. They believe that impact should be reinforced by linking the results of self-assessment to subsequent learning activities including continuing medical education (Galbraith, et al., 2008).

A bit distant from previous, still in connection to self-assessment is review of use of personal digital assistants (PDAs) by practising physicians (Ranson, et al., 2007). Among the value of PDAs in accessing information for making clinical decisions and for patient education, PDA use for learning portfolio 
intended to encourage documentation of reflection on practice and medical education was mentioned. It is remarkable that they mention: "Access to information is important, but it is not a predictor of change. Reflection, as a form of mental processing, allows physicians to make information and knowledge more meaningful" (Ranson, et al., 2007, p. 229).

The difference between 'continuing medical education' and 'continuing professional development' is stressed in "Self-Assessment in CPD: Lessons from the UK Undergraduate and Postgraduate Education Domains" (Dornan, 2008). Dornan argues that continuing professional development explicitly links education to change in practice and gives self-assessment (especially in the form of reflection) a central place in personal development. In the abstract of the article is said that it considers how a positive system of self-assessment and professional self-regulation could be operationalized (Dornan, 2008), so it is even more unfortunate that the author of this review did not have access to the full text.

Assessment of the practicing physician is also discussed in Holmboe's respective article (Holmboe, 2008). There are two forces highlighted: pressure to change the nature of continuing medical education and pressure to hold individual physicians more accountable for the care they provide. Holmboe argues that comprehensive physician assessment provides such an opportunity, and many assessment methods and tools exist that can facilitate the integration of continuing medical education and quality. Holmboe writes: "Using a multifaceted physician-level performance assessment system has substantial potential to align the public's need and desire to ensure their physician is competent, at a minimum, with providing the physician with meaningful, actionable information and data to improve performance and engage in transformative learning" (Holmboe, 2008, p.4). However, it was not possible for the author of this review to explore how exactly Holmboe suggests physicians to engage in transformative learning or other aspects of continuing medical education.

Transformative learning example is described through cultural immersion experience for nursing students in Adamshick \& August-Brady (2012). It is convincing that there are positive short- and long-term effects on the personal and professional lives of the participants after weeklong immersion; however, it's possible translation to continuing medical education is not so clear.

Another article mainly devoted to nursing study process is discussing Transformative Learning Framework for nurse educators (Mcallister, 2011). Although continuing medical education is not explicitly mentioned in the article, several main ideas could be 'borrowed' for implementation as well in continuing medical education. Like, for educators to allow those learning to experience disorienting dilemmas rather than protect from these. 
It is valuable because can become a trigger for deep learning, reflection and arriving at new understandings, thus better equip learners for future practice and for the advancement of the profession (Mcallister, 2011).

An interesting example of transformative learning is found in an article describing Change Laboratory intervention to implement changes in paediatric outpatient clinic (Skipper, et al., 2016). Although it doesn't claim itself to be continuing medical education example (in its most often used sense), it pictures a great example of workplace learning. Indeed, "because the cultural and technological practice of a medical department constantly change, medical researchers and practitioners need tools to analyse and intervene in a department's practice of care and continuing education" (Skipper, et al., 2016, p. 2).

There is only one study capturing the lived experience of attendees of a continuing medical education course (Sokol \& Shaughnessy, 2018). It is done using hermeneutic phenomenological approach through individual interviews, focus groups, and observations. It is underlined that for behaviour change to occur, participants often need to consciously reject previous ideas and transform their way of thinking. Indeed, participants of this study described how taking part in the continuing medical education course evoked strong emotional responses, facilitated personal transformation, and propelled expedited behaviour change resulting in a newfound sense of self-efficacy, confidence, and ownership in their ability to make medical decisions. It is concluded that transformative learning opportunities would promote translation into practice if learners are supported while going through personalized meaning-making process (Sokol \& Shaughnessy, 2018).

Among others, an article found to be very informative, even if not seen as such from the surface, is Brendel's Framework for narrative-driven transformative learning in medicine (Brendel, 2009). Superficially looking, it talks about patient learning experiences and puts clinician into role of teacher. However, there is a thread throughout the article aiming to show almost endless possibilities for clinicians to learn themselves. One could argue that there is no reference to continuing medical education in the article. Yes, it's true; however, touching the thread opens understanding that clinicians are learning every day together with their patients. For instance, "With each grave prognosis, health care practitioners themselves should strive for a deeper understanding (..). Maintaining a learning journal will not only inform subsequent encounters with dying patients but may also be shared effectively in communities of practice within hospitals and similar institutions" (Brendel, 2009, pp. 40-41).

Likewise, conversations between physicians and their patients concerning terminal conditions are seen as transformative learning source 
in Moon's article (Moon, 2008). Acknowledging that such encounters comprise complex grief dynamics, they are also described as opportunities for personal insights for physicians, and their more authentic presence. Transformative learning is emphasized throughout the article, although not always mentioning the term itself, e.g., saying that physicians' commitment to a lifelong agenda of refining their world-view orientation is crucial (Moon, 2008).

Transformative changes are possible if we consciously acknowledge them. Why don't make it part of continuing medical education?

Challenges are clearly stated in the article discussing arts-based critical inquiry in nursing and interdisciplinary professional education (Macdonnell \& Macdonald, 2011): (a) many competing priorities within contemporary competency-based professional curricula; (b) processes, which foster construction of knowledge and relationships among learners, affirming emotional dimensions of learning and cognitive uncertainty, are in direct contrast to the prevailing view of critical inquiry in health professions (nursing, medicine); (c) although many educators have employed narrative and other arts-based approaches to address diversity and interpersonal relationships, this approach is not always visible in mainstream professional education; (d) interactive small group learning contrasts sharply with superficial and strategic learning which are often the default learning modes in medical education (Macdonnell \& Macdonald, 2011).

Margaret McAllister, nursing teacher, shares her vision for nursing educators to come together in communities of practice to talk about the challenging aspects of nursing and ways these challenges can be reframed and reapproached through education. She clearly states that her vision is underpinned by the pedagogy of Transformative Learning. In her article she discusses the courage necessary to teach a values-based curriculum. Arguing the value of a pedagogy for nursing that moves beyond a preoccupation with techniques and medical knowledge, she also does not dismiss this learning (McAllister, 2015). It would be interesting to find out her views regarding continuing medical education, what has not been of special attention in reviewed article.

However, there is another publication co-authored by McAllister (McAllister, et al., 2016), where they discuss implementing learning experiences that challenge nursing students to think deeply and broadly about the experiences they encounter, to question their previous assumptions and prejudices, to consider the world of healthcare through a new lens, and to reflect on and learn from the process. There is presentation of film exemplars and related teaching strategies designed to facilitate transformative learning and development of ethical comportment in the article (McAllister, et al., 2016). Although continuing medical 
education is not explicitly mentioned, motivated educator could find at least inspiration for possible use of methods described in the article also in continuing medical education.

\section{Conclusion}

There were 16 articles reviewed in order to find out the scope and the nature of research and studies devoted to transformative learning in continuing medical education.

Characteristics of articles included in this literature review:

$\begin{array}{lll}\text { Language } & - & \text { English } \\ \text { Peer-reviewed } & - & \text { yes } \\ \text { Published (years) } & - & \text { 2007-2018 }\end{array}$

There was substantial motivation to carry out this literature review for the author being adult educator working in continuing medical education and recently growing his own interest in transformative learning.

The first finding is surprising: there are only few studies clearly stating both - transformative learning and continuing medical education - as their keywords. (Anecdotally, none of those were accessible in full text for the author.)

Although it was expectation to find more studies discussing operational level of introducing transformative learning in continuing medical education, it was only one article found capturing the lived experience of attendees of a continuing medical education course: Sokol \& Shaughnessy (2018). A bit distant from that, with possible practical implications, is study where participants were encouraged to use personal digital assistants also for documentation of reflection on practice and medical education (Ranson, et al., 2007), and example of workplace learning involving elements of transformative learning (Skipper et al., 2016).

Conceptual (theoretical) frameworks of possible introduction of transformative learning within continuing medical education are discussed in several studies (Mcwilliam, 2007; Mcallister, 2011; Brendel, 2009).

Some of studies are depicturing transformative learning within undergraduate or graduate study context, mainly - in nursing (Adamshick \& August-Brady, 2012; Mcallister, 2011; Macdonnell \& Macdonald, 2011; McAllister, 2015; McAllister, et al., 2016).

There are studies highlighting the importance of self-monitoring and self-reflection of medical professionals for transformational learning to take place (Epstein, et al., 2008; Galbraith, et al., 2008; Ranson, et al., 2007; Holmboe, 2008). Some of them are courageous enough to admit 
that individual learners might interpret self-assessment results inaccurately (Galbraith, et al., 2008); others highlighting patient learning and subsequently - physician learning (Brendel, 2009; Moon, 2008).

Another strain of studies underlines importance of continuing medical education to adopt new teaching and learning approaches (Sargeant, 2009; Dornan, 2008; Macdonnell \& Macdonald, 2011; McAllister, 2015; McAllister, et al., 2016), even suggesting 'continuing professional development' as more accurate term instead of 'continuing medical education' (Dornan, 2008).

In conclusion let me quote one of the articles reviewed: "Creating spaces for collective dialogue and deep reflection seems more urgent than it has ever been" (Macdonnell \& Macdonald, 2011, p. 217). Now this seems to be appropriate slogan for transformative learning to be introduced more into continuing medical education.

\section{References}

Adamshick, \& August-Brady. (2012). Reclaiming the Essence of Nursing: The Meaning of an Immersion Experience in Honduras for RN to Bachelor of Science Students. Journal of Professional Nursing, 28(3), 190-198.

Brendel, W. (2009). A Framework for Narrative-Driven Transformative Learning in Medicine. Journal of Transformative Education, 7(1), 26-43.

Dornan, T. (2008). Self-Assessment in CPD: Lessons from the UK Undergraduate and Postgraduate Education Domains. Journal of Continuing Education in the Health Professions, 28(1), 32-37.

Epstein, R., Siegel, D., \& Silberman, J. (2008). Self-Monitoring in Clinical Practice: A Challenge for Medical Educators. Journal of Continuing Education in the Health Professions, 28(1), 5-13.

Galbraith, R., Hawkins, R., \& Holmboe, E. (2008). Making Self-Assessment More Effective. Journal of Continuing Education in the Health Professions, 28(1), 20-24.

Holmboe, E. (2008). Assessment of the Practicing Physician: Challenges and Opportunities. Journal of Continuing Education in the Health Professions, 28(S1), S4-S10.

Macdonnell, J., \& Macdonald, G. (2011). Arts-Based Critical Inquiry in Nursing and Interdisciplinary Professional Education: Guided Imagery, Images, Narratives, and Poetry. Journal of Transformative Education, 9(4), 203-221.

Mcallister, Levett-Jones, Petrini, \& Lasater. (2016). The viewing room: A lens for developing ethical comportment. Nurse Education in Practice, 16(1), 119-124.

Mcallister, M. (2011). STAR: A Transformative Learning Framework for Nurse Educators. Journal of Transformative Education, 9(1), 42-58.

Mcallister, M. (2015). Exploring transformative learning and the courage to teach a values based curriculum. Nurse Education in Practice, 15(6), 480-484.

Mcwilliam, C. (2007). Continuing Education at the Cutting Edge: Promoting Transformative Knowledge Translation. Journal of Continuing Education in the Health Professions, 27(2), 72-79. 
Mezirow, J. (2003). Transformative learning as discourse. Journal of Transformative Education, 1(1): 58-63. doi:10.1177/1541344603252172.

Moon, P. (2008). Death-Talks: Transformative Learning for Physicians. American Journal of Hospice and Palliative Medicine, 25(4), 271-277.

Ranson, S., Boothby, J., Mazmanian, P., \& Alvanzo, A. (2007). Use of Personal Digital Assistants (PDAs) in Reflection on Learning and Practice. Journal of Continuing Education in the Health Professions, 27(4), 227-233.

Sargeant, J. (2009). Theories to Aid Understanding and Implementation of Interprofessional Education. Journal of Continuing Education in the Health Professions, 29(3), 178-184.

Skipper, M., Musaeus, P., \& Nahr, S. (2016). The paediatric change laboratory: Optimising postgraduate learning in the outpatient clinic. BMC Medical Education, 16(42), N/a.

Sokol, R. G., \& Shaughnessy, A. F. (2018). Making the most of continuing medical education: Evidence of transformative learning during a course in evidence-based medicine and decision making. Journal of Continuing Education in the Health Professions, 38(2), 102-109. 